Acta technologica agriculturae 1

Nitra, Slovaca Universitas Agriculturae Nitriae, 2013, p. 5-9

\title{
COMPARISON OF SUMMER AND WINTER TYRES ON A DRY AND SNOWY SURFACE
}

\author{
Ivan JANOŠKO, Tomáš POLONEC, Jozef CHRASTINA \\ Slovak University of Agriculture in Nitra, Slovakia
}

\begin{abstract}
The paper describes the comparison of braking properties of summer and winter tyres on a vehicle Škoda Octavia II, 2.0 TDI (103 kW), with summer tyres Michelin Pilot Primacy 225/45 R17 91W and winter tyres Dunlop SP Winter Sport 3D 195/65 R15 91T. Testing was done in summer on a dry asphalt road and in winter on a snowy asphalt road with compacted snow without gritting. A device for the measuring of deceleration was XL Meter Pro Alpha.
\end{abstract}

Keywords: braking, vehicle, deceleration, grip, tyre

Tyres are an important part of vehicles. They transfer traction, braking and lateral forces. Further, they transfer the weight of a vehicle to the ground and absorb shocks from road bumps. There is also required a low rolling resistance in order to reduce fuel consumption, and rolling with a low noise and low transfer of vibrations into the cabin.

The operation of vehicles with modern tyres on roads and motorways represents a new standard of drive comfort and transport safety. The implementation and use of winter tyres for passenger cars, light commercial vehicles and buses is now a very frequent question. The use of such tyres is confronted with their higher costs on one hand, and with anticipated improvements of adhesion properties, especially in difficult winter conditions under low temperatures, in the presence of a snow cover and also on frozen roads, on the other hand.

The objective of this paper is to give further information on the behaviour of summer and winter tyres in defined conditions in terms of transferring the braking forces during braking in a limited condition of $100 \%$ slide on a dry road, and to follow the results of Janoško et al. (2007-2010), Abrahám et al. (2009, 2012), Jamrichová et al. (2003, 2012), and Sloboda et al. (2008).

\section{Material and methods}

The behaviour of selected summer and winter tyres was assessed on a dry asphalt road under temperatures recommended by manufacturers for replacing the summer and winter tyres.

Initial speeds were selected from the interval of 40,60 and $90 \mathrm{~km} \cdot \mathrm{h}^{-1}$, considering the wear of tyres and the length of a test road.

For the purpose of these experiments, summer and winter tyres were mounted on a vehicle with an $A B S$ braking system. In addition to monitoring the reached deceleration values on individual types of tyres, also the age of tyres was taken into account.

Experimental measurements were performed with summer and winter tyres, on a dry asphalt-concrete road, next to Janíkovce village, under an air temperature of 13.0-14.5 ${ }^{\circ} \mathrm{C}$. Comparative measurements were also done in winter, on winter tyres with speeds 40,60 , and $90 \mathrm{~km} . \mathrm{h}^{-1}$, and subsequently on summer tyres with speeds 40,50 , and $70 \mathrm{~km} \cdot \mathrm{h}^{-1}$. The measurement was performed on a side road covered with snow, with a smooth, compacted snow of 1-2 cm thickness without gritting, under air temperature $t=-1.5^{\circ} \mathrm{C}$. On the base of those measurements, we have assessed the suitability of using the tested types of tyres in the summer and winter season.

\section{External conditions during measurements}

Air temperature: $13.0-14.5^{\circ} \mathrm{C}$ (summer measurements)

$$
-1.5^{\circ} \mathrm{C} \text { (winter measurements) }
$$

Wind: light north-east

Place of measurement: communication at Janíkovce village - Nitra, Vel'ký Cetín

Surface type: bitumen road, dry

\section{Vehicle}

Škoda Octavia II, 2.0 TDI, technical parameters (Table 1) Tyres: Dunlop SP Winter Sport 3D 195/65 R15 91T (winter tyre)

Michelin Pilot Primacy 225/45 R17 91W (summer tyre)

\section{Measuring device}

Gravimetric XL meter (accelerating and decelerating), with software, the precision of measurement: $\delta= \pm 5 \%$

Table 1 Technical parameters of Škoda Octavia II, 2.0 TDI

\begin{tabular}{|l|c|}
\hline Vehicle make & Škoda Octavia II \\
\hline \hline Engine displacement & $1,968 \mathrm{~cm}^{3}$ \\
\hline Engine maximum power / RPM & $103 \mathrm{~kW} / 4,000 \mathrm{~min}^{-1}$ \\
\hline Drive axle & Front \\
\hline Gearbox & Mechanical 6-speed \\
\hline Type of fuel & Diesel \\
\hline Standby weight & $1,335 \mathrm{~kg}$ \\
\hline Brakes front / rear & Disc brakes / disc brakes \\
\hline Year of manufacture & 2007 \\
\hline
\end{tabular}



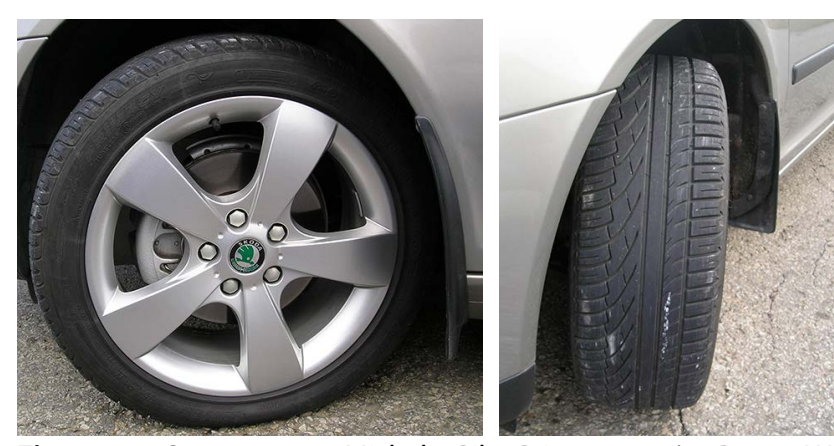

Figure 1 Summer tyres Michelin Pilot Primacy 225/45 R17 91 W

Table 2 Technical parameters of the tested summer tyres

\begin{tabular}{|l||c|}
\hline Type of tyres & $\begin{array}{c}\text { Michelin Pilot Primacy } \\
\text { 225/45 R17 91 W }\end{array}$ \\
\hline \hline Year of manufacture (week/year) & $16 / 2007$, travelled 5,000 km \\
\hline Pressure in the tyre FL & $210 \mathrm{kPa}$ \\
\hline Pressure in the tyre FR & $210 \mathrm{kPa}$ \\
\hline Pressure in the tyre RL & $220 \mathrm{kPa}$ \\
\hline Pressure in the tyre RR & $220 \mathrm{kPa}$ \\
\hline Depth of tread pattern FL & $7.5-7.8 \mathrm{~mm}$ \\
\hline Depth of tread pattern FR & $7.5-7.8 \mathrm{~mm}$ \\
\hline Depth of tread pattern RL & $7.5-7.8 \mathrm{~mm}$ \\
\hline Depth of tread pattern RR & $7.5-7.8 \mathrm{~mm}$ \\
\hline
\end{tabular}
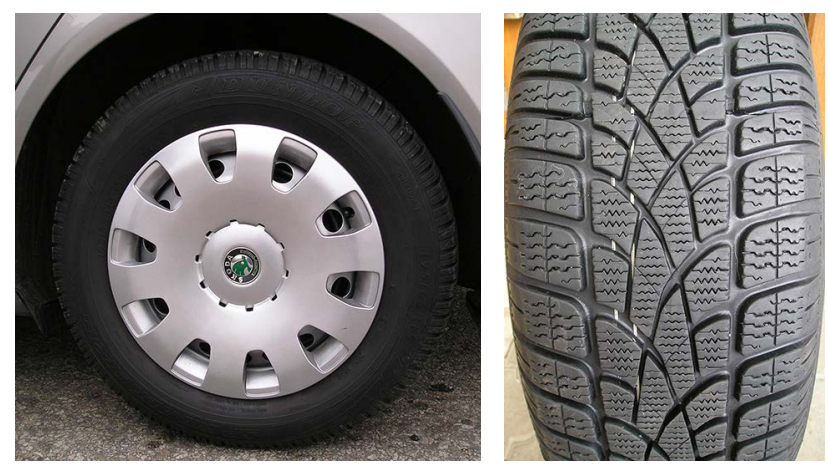

Figure 2 Winter tyres Dunlop SP Winter Sport 3D 195/65 R15 91 T

Table 3 Technical parameters of the tested winter tyres

\begin{tabular}{|l||c|}
\hline Type of tyres & $\begin{array}{c}\text { Dunlop SP Winter Sport 3D } \\
\text { 195/65 R15 91T }\end{array}$ \\
\hline \hline Year of manufacture (week/year) & $17 / 2006$, travelled 3,000 km \\
\hline Pressure in the tyre FL & $220 \mathrm{kPa}$ \\
\hline Pressure in the tyre FR & $220 \mathrm{kPa}$ \\
\hline Pressure in the tyre BL & $230 \mathrm{kPa}$ \\
\hline Pressure in the tyre BR & $230 \mathrm{kPa}$ \\
\hline Depth of tread pattern FL & $7.5-7.8 \mathrm{~mm}$ \\
\hline Depth of tread pattern FR & $7.5-7.8 \mathrm{~mm}$ \\
\hline Depth of tread pattern BL & $7.5-7.8 \mathrm{~mm}$ \\
\hline Depth of tread pattern BR & $7.5-7.8 \mathrm{~mm}$ \\
\hline
\end{tabular}

A mathematical model for the determination of kinematic parameters of the vehicle is based on the motion of a slowing body, where the following equations shall apply to time:

$$
\int_{t_{1}}^{t_{2}} F \cdot d t=\int_{v_{1}}^{v_{2}} d(m \cdot v)
$$

for distance:

$$
\int_{s_{1}}^{s_{2}} F \cdot d s=\int_{v_{1}}^{v_{2}} d\left(\frac{1}{2} m \cdot v^{2}\right)
$$

respectively:

$$
s=\int_{0}^{t} v \cdot d t=\int_{0}^{t} a \cdot t \cdot d t=\frac{a \cdot t^{2}}{2}=\frac{v^{2}}{2 a}
$$

where:

$F \quad$ - braking force on the wheels

$m$ - mass of the vehicle

$v \quad$ - initial vehicle speed

$s$ - braking distance

a - deceleration

$t$ - time of braking

For a detailed understanding of changes in slowdown, it is necessary to know the instantaneous deceleration over time. Exact deceleration was obtained by the gravity decelerator, where the examined deceleration MFDD (mean fully developed deceleration) is defined as follows:

$$
M F D D=\frac{v_{b}^{2}-v_{e}^{2}}{2.92 \cdot\left(s_{e}-s_{b}\right)}, \quad \mathrm{m} . \mathrm{s}^{-2}
$$

where:

$v_{0}$ - initial speed at the start of braking, $\mathrm{km} \cdot \mathrm{h}^{-1}$

$v_{b}-k_{1} v_{0}, k_{1}=0.8, \mathrm{~km} \cdot \mathrm{h}^{-1}$

$v_{e}-k_{2} v_{0}, k_{2}=0.1, \mathrm{~km} \cdot \mathrm{h}^{-1}$

$s_{b}$ - distance travelled by the vehicle between speeds $v_{0}$ and $v_{b^{\prime}} \mathrm{m}$

$s_{e}$ - distance travelled by the vehicle between speeds $v_{0}$ and $v_{e^{\prime}} \mathrm{m}$

\section{Results and discussion}

The braking deceleration of tyres in different conditions was implemented in 12 separate runs for different speeds. Each experimental measuring of deceleration was recorded with a sampling frequency of $200 \mathrm{~Hz}$, and waveforms of velocity and travel were subsequently determined. A record was prepared from each limited deceleration, and all the results were prepared in the form of a table (Tables 4-7).

Some courses, as illustrated in Figures 3 and 4, were selected from individual measurements. 
Table 4 Results of measuring the summer tyres Michelin Pilot Primacy 225/45 R17 91W under temperature $t=13.0-14.5^{\circ} \mathrm{C}$, one person, dry surface

\begin{tabular}{|c|c|c|c|}
\hline Vehicle & \multicolumn{3}{|c|}{ Škoda Octavia II, 2.0 TDI - with ABS } \\
\hline Type of tyres & \multicolumn{3}{|c|}{ Michelin Pilot Primacy 225/45 R17 91W } \\
\hline Type of road & \multicolumn{3}{|c|}{ Dry, asphalt-concrete } \\
\hline Prescribed initial speed & $40 \mathrm{~km} \cdot \mathrm{h}^{-1}$ & $60 \mathrm{~km} \cdot \mathrm{h}^{-1}$ & $90 \mathrm{~km} \cdot \mathrm{h}^{-1}$ \\
\hline Real initial speed $-v_{0}$ & $41.54 \mathrm{~km} \cdot \mathrm{h}^{-1}$ & $60.50 \mathrm{~km} \cdot \mathrm{h}^{-1}$ & $91.03 \mathrm{~km} \cdot \mathrm{h}^{-1}$ \\
\hline Braking distance $-s_{0}$ & $8.09 \mathrm{~m}$ & $16.02 \mathrm{~m}$ & $38.44 \mathrm{~m}$ \\
\hline Braking time $-T_{b r}$ & $1.33 \mathrm{~s}$ & $1.84 \mathrm{~s}$ & $2.85 \mathrm{~s}$ \\
\hline Value of deceleration - MFDD & $8.95 \mathrm{~m} \cdot \mathrm{s}^{-2}$ & $9.87 \mathrm{~m} \cdot \mathrm{s}^{-2}$ & $9.74 \mathrm{~m} \cdot \mathrm{s}^{-2}$ \\
\hline
\end{tabular}

Table 5 Results of measuring the winter tyres Dunlop SP Winter Sport 3D 195/65 R15 91T under temperature $t=13.0-14.5^{\circ} \mathrm{C}$, one person, dry surface

\begin{tabular}{|c|c|c|c|}
\hline Vehicle & \multicolumn{3}{|c|}{ Škoda Octavia II, 2.0 TDI - with ABS } \\
\hline Type of tyres & \multicolumn{3}{|c|}{ Dunlop SP Winter Sport 3D 195/65 R15 91T } \\
\hline Type of road & \multicolumn{3}{|c|}{ Dry, asphalt-concrete } \\
\hline Prescribed initial speed & $40 \mathrm{~km} \cdot \mathrm{h}^{-1}$ & $60 \mathrm{~km} \cdot \mathrm{h}^{-1}$ & $90 \mathrm{~km} \cdot \mathrm{h}^{-1}$ \\
\hline Real initial speed $-v_{0}$ & $42.66 \mathrm{~km} \cdot \mathrm{h}^{-1}$ & $63.40 \mathrm{~km} \cdot \mathrm{h}^{-1}$ & $90.98 \mathrm{~km} \cdot \mathrm{h}^{-1}$ \\
\hline Braking distance $-s_{0}$ & $9.50 \mathrm{~m}$ & $21.5 \mathrm{~m}$ & $44.35 \mathrm{~m}$ \\
\hline Braking time $-T_{b r}$ & $1.56 \mathrm{~s}$ & $2.39 \mathrm{~s}$ & $3.38 \mathrm{~s}$ \\
\hline Value of deceleration - MFDD & $7.89 \mathrm{~m} \cdot \mathrm{s}^{-2}$ & $7.10 \mathrm{~m} \cdot \mathrm{s}^{-2}$ & $7.72 \mathrm{~m} \cdot \mathrm{s}^{-2}$ \\
\hline
\end{tabular}

Table 6 Results of measuring the summer tyres Michelin Pilot Primacy 225/45 R17 91W under temperature $t=-1.5^{\circ} \mathrm{C}$, one person, snowy surface

\begin{tabular}{|c|c|c|c|}
\hline Vehicle & \multicolumn{3}{|c|}{ Škoda Octavia II, 2.0 TDI - with ABS } \\
\hline Type of tyres & \multicolumn{3}{|c|}{ Michelin Pilot Primacy 225/45 R17 91W } \\
\hline Type of road & \multicolumn{3}{|c|}{ road covered with a compacted snow of $1-2 \mathrm{~cm}$, without gritting } \\
\hline Prescribed initial speed & $40 \mathrm{~km} \cdot \mathrm{h}^{-1}$ & $50 \mathrm{~km} \cdot \mathrm{h}^{-1}$ & $70 \mathrm{~km} \cdot \mathrm{h}^{-1}$ \\
\hline Real initial speed $-v_{0}$ & $33.65 \mathrm{~km} \cdot \mathrm{h}^{-1}$ & $50.47 \mathrm{~km} \cdot \mathrm{h}^{-1}$ & $64.12 \mathrm{~km} \cdot \mathrm{h}^{-1}$ \\
\hline Braking distance $-s_{0}$ & $35.94 \mathrm{~m}$ & $75.52 \mathrm{~m}$ & $125.94 \mathrm{~m}$ \\
\hline Braking time $-T_{b r}$ & $7.64 \mathrm{~s}$ & $11.20 \mathrm{~s}$ & $14.40 \mathrm{~s}$ \\
\hline Value of deceleration - MFDD & $1.27 \mathrm{~m} \cdot \mathrm{s}^{-2}$ & $1.31 \mathrm{~m} \cdot \mathrm{s}^{-2}$ & $1.26 \mathrm{~m} \cdot \mathrm{s}^{-2}$ \\
\hline
\end{tabular}

Table 7 Results of measuring the winter tyres Dunlop SP Winter Sport 3D 195/65 R15 91T under temperature $t=-1.5^{\circ} \mathrm{C}$, one person, snowy surface

\begin{tabular}{|l||c|c|c|}
\hline \multicolumn{1}{|l||}{ Vehicle } & \multicolumn{2}{c|}{ Škoda Octavia II, 2.0 TDI - with ABS } \\
\hline \hline Type of tyres & \multicolumn{2}{|c|}{ Dunlop SP Winter Sport 3D 195/65 R15 91T } \\
\hline Type of road & \multicolumn{1}{|c|}{ road covered with a compacted snow of 1-2 cm, without gritting } \\
\hline Prescribed initial speed & $40 \mathrm{~km} \cdot \mathrm{h}^{-1}$ & $60 \mathrm{~km} \cdot \mathrm{h}^{-1}$ & $90 \mathrm{~km} \cdot \mathrm{h}^{-1}$ \\
\hline Real initial speed $-v_{0}$ & $38.01 \mathrm{~km} \cdot \mathrm{h}^{-1}$ & $62.80 \mathrm{~km} \cdot \mathrm{h}^{-1}$ & $87.79 \mathrm{~km} \cdot \mathrm{h}^{-1}$ \\
\hline Braking distance $-s_{0}$ & $19.91 \mathrm{~m}$ & $44.50 \mathrm{~m}$ & $91.44 \mathrm{~m}$ \\
\hline Braking time $-T_{b r}$ & $3.83 \mathrm{~s}$ & $5.51 \mathrm{~s}$ & $7.90 \mathrm{~s}$ \\
\hline Value of deceleration - MFDD & $3.08 \mathrm{~m} \cdot \mathrm{s}^{-2}$ & $3.46 \mathrm{~m} \cdot \mathrm{s}^{-2}$ & $3.36 \mathrm{~m} \cdot \mathrm{s}^{-2}$ \\
\hline
\end{tabular}



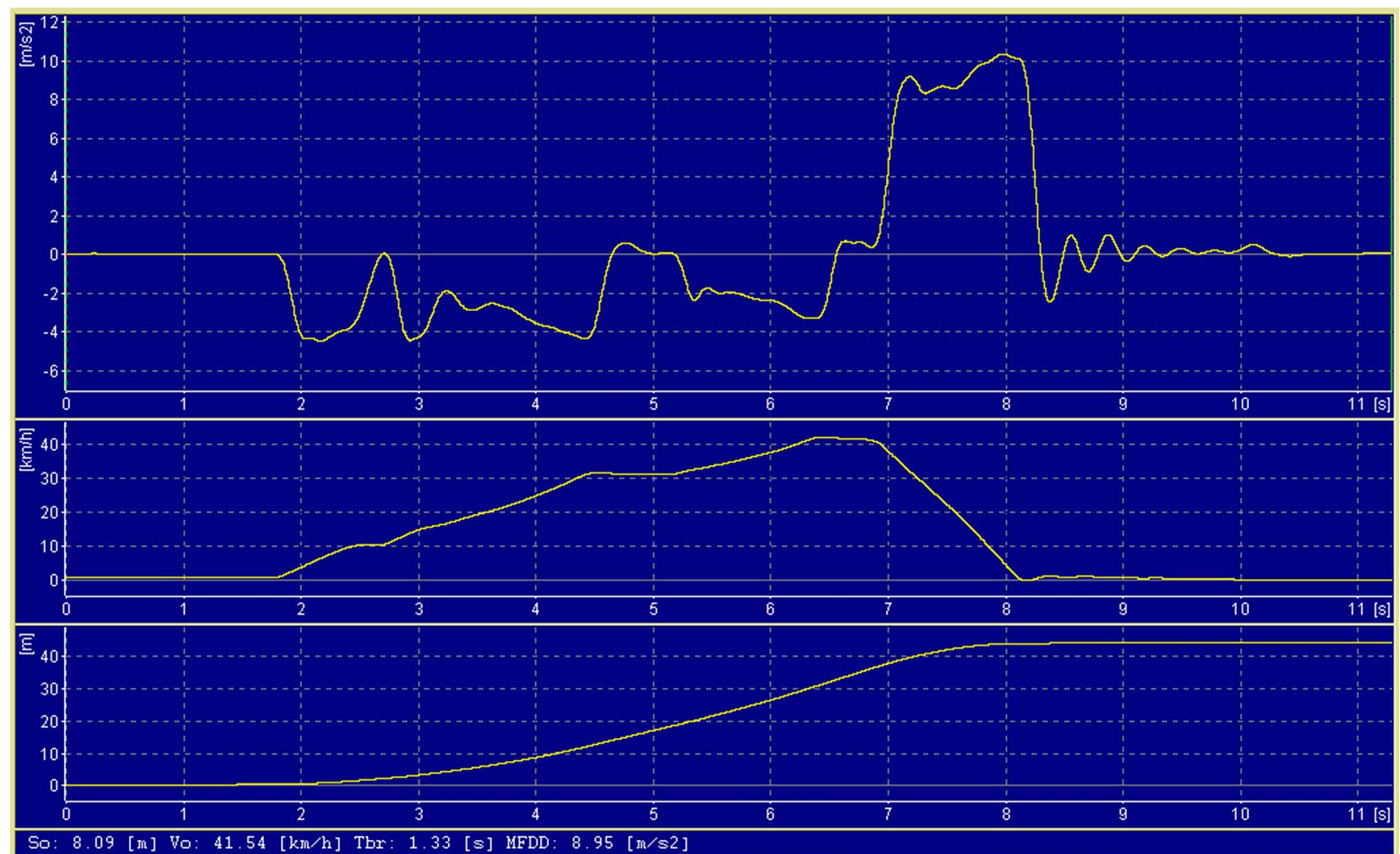

Figure 3 Record of limit deceleration of Škoda Octavia II, 2.0 TDI, Michelin Pilot Primacy 225/45 R17 91W, year of manufacture 2007 , tyre tread depth $7.5-7.8 \mathrm{~mm}$, speed $41.54 \mathrm{~km} \cdot \mathrm{h}^{-1}$, asphalt-concrete road, dry surface, $t=14.5^{\circ} \mathrm{C}$, one person
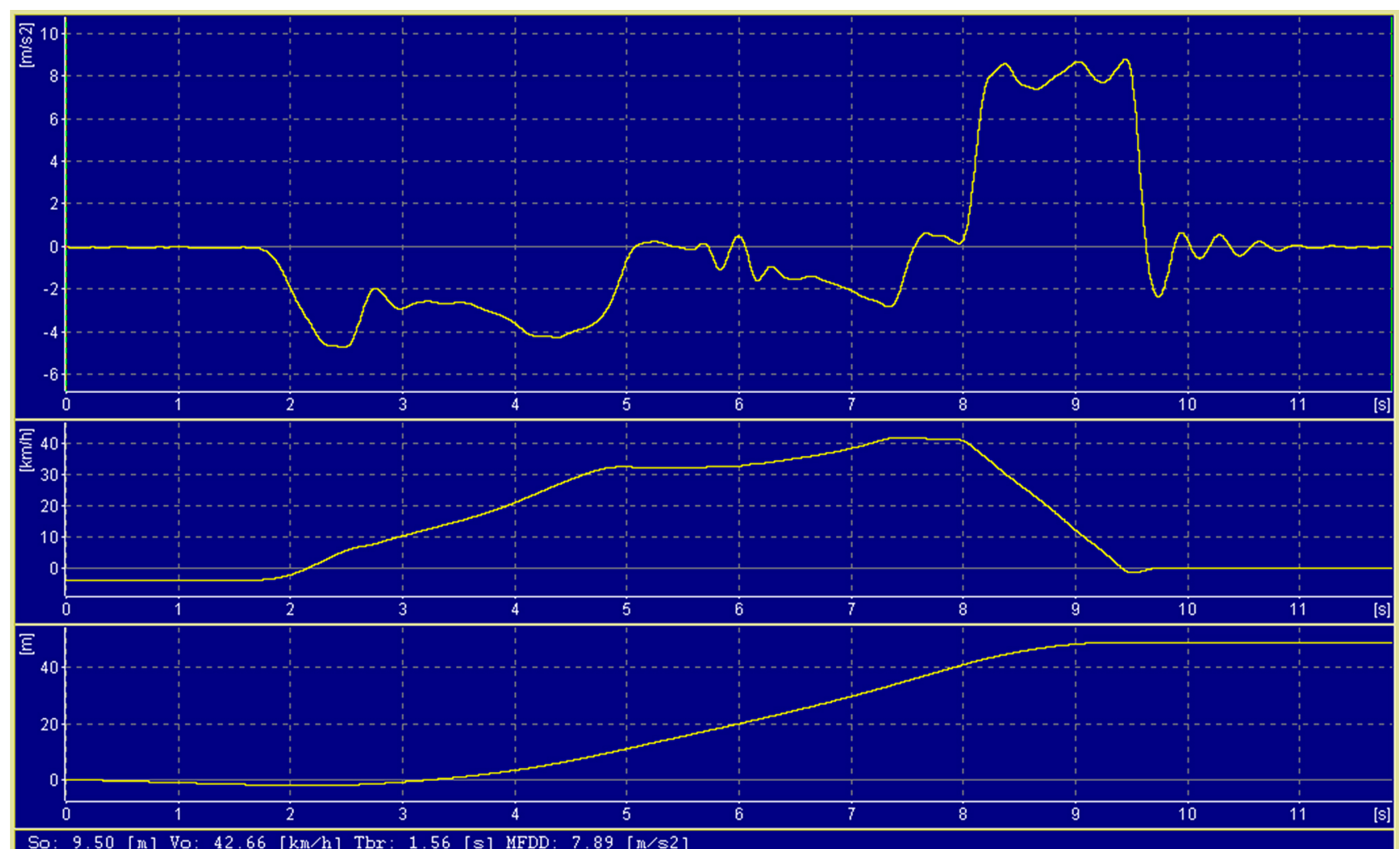

Figure 4 Record of limit deceleration of Škoda Octavia II, 2.0TDI, Dunlop SP Winter Sport 3D 195/65 R15 91T, year of manufacture 2006 , tyre tread depth $7.5-7.8 \mathrm{~mm}$, speed $42.66 \mathrm{~km} \cdot \mathrm{h}^{-1}$, asphalt-concrete, dry surface, $t=13.0^{\circ} \mathrm{C}$, one person 


\section{Conclusion}

The measured and aggregated results lead to the following conclusions:

- During the test of Škoda Octavia II with ABS in summer $\left(t=13.0-14.5^{\circ} \mathrm{C}\right)$, there was found a worse braking deceleration of winter tyres Dunlop SP Winter Sport 3D 195/65 R15 91T (year of manufacture 2006) as compared to summer tyres Michelin Pilot Primacy 225/45 R17 91W (year of manufacture 2007) on a dry road. It was the case of tyres after running-in, with about 3,000-5,000 km run. The measured results show that the summer tyres Michelin with a speed of $40-90 \mathrm{~km} \cdot \mathrm{h}^{-1}$ reached the mean deceleration in the interval $a=8.95-9.87 \mathrm{~m} . \mathrm{s}^{-2}$, and the winter tyres Dunlop in the interval $a=7.1-7.89 \mathrm{~m} \cdot \mathrm{s}^{-2}$, representing a reduction of deceleration amounting to about $20-21 \%$. However, at such a difference, winter tyres had a comparable deceleration to less powerful summer tyres. Excellent results of the summer tyres Michelin in combination with ABS reached deceleration $a=0.9-1.0 \mathrm{~g}(g-$ gravimetric acceleration), which is actually a noteworthy value.

- When testing Škoda Octavia II with ABS in winter ( $t=$ $-1.5^{\circ} \mathrm{C}$ ), there was observed a worse braking deceleration of the summer tyres Michelin Pilot Primacy 225/45 R17 $91 \mathrm{~W}$ as compared to the winter tyres Dunlop SP Winter Sport 3D 195/65 R15 91T on a snowy road with a snow height of $1-2 \mathrm{~cm}$. Based on the measured and aggregated experiments, it is possible to state that with the tested types of winter tyres we have reached better deceleration results at $a=3.08-3.46 \mathrm{~m} \cdot \mathrm{s}^{-2}$. The Michelin summer tyres reached deceleration at $a=1.26-1.31 \mathrm{~m} . \mathrm{s}^{-2}$, which represents a decrease of deceleration by ca. 59-62 \%. Such a significant reduction in deceleration will result in more than twice the braking distance. In addition to a worse compound in winter conditions, an unfavourable outcome of summer tyres is a result of a greater width of summer tyres, too.

- It follows from the above-mentioned facts that a suitable tread pattern as well as the composition of the compound itself has a significant effect on vehicle behaviour in limit situations, and the alternating of summer and winter tyres in different seasons has its own significance. Especially good winter tyres in winter represent a large increase in braking deceleration. These considerations are valid for age-comparable tyres.

\section{Acknowledgement}

This paper was prepared with the support of the VEGA No $1 / 0519 / 13$ project 'Solution of changes to the technical and exploitative features of mobile energetic resources in terms of using different fuels, their effective use with monitoring of selected technical, energetic, environmental and emission parameters'.

\section{References}

ABRAHÁM, R. - JABLONICKÝ, J. - VARGA, F. - DRLIČKA, R. 2009. Design of increase interaction properties of tyres in worsenees climatic conditions. In Traktori i pogonske mašine (Tractors and Power Machines), vol. 14, no. 1, pp. 64-69. ISSN 0354-9496.

ABRAHÁM, R. - VARGA, F. - MAJDAN, R. - MOJŽIŠ, M. 2012. Design of improvement of adhesive properties of tyres on snow, ice and soil. In Acta technologica agriculturae, vol. 15, no. 1, pp. 1-4. ISSN 1335-2555.

JAMRICHOVÁ, Z. - ŠIMA, A. - ELIAŠ, J. 2003. Diagnostika strojov a zariadení l. 1. vyd. Trenčín : TnUAD. 196 s. ISBN 80-88914-84-1.

JAMRICHOVÁ, Z. - STODOLA, J. - STODOLA, P. 2012. Diagnostika strojov a zariadení. 1. vyd. Žilina : EDIS. 281 s. ISBN 978-80-554-0385-4.

JANOŠKO, I. 2007. Testovanie deceleračných vlastností vozidiel a pneumatík. In Nové trendy v konštrukcii a exploatácii vozidiel „Vozidlá 2007" : medzinárodná vedecká konferencia. Nitra : SPU, s. 80-87. ISBN 978-80-8069-942-0.

JANOŠKO, I. - ŠIMOR, R. 2008. Testovanie deceleračných vlastností vozidiel a pneumatík II. In Nové trendy v konštrukcii a exploatácii vozidiel „VOZIDLÁ 2008“ : medzinárodná vedecká konferencia. Nitra : SPU, s. 85-91. ISBN 978-80-552-0106-1.

JANEC, D. - JANOŠKO, I. 2009. Posúdenie zimných a letných pneumatik pri brzdení. In Medzinárodná študentská vedecká konferencia v Nitre. Nitra : SPU, s. 164-170. ISBN 978-80-552-0208-2.

KOHUT, P. - KUBIATKO, T. 2000. Brzdenie vybraného súboru vozidel. In Znalectvo, Žilina, 2000, č. 2, s. 17-30. ISSN 1335-1133.

SLOBODA, A. - FERENCEY, V. - HLAVŇA, V. - TKÁČ, Z. et al. 2008. Konštrukcia kolesových a pásových vozidiel. Košice : Vienala. 547 s. ISBN 978-80-89232-28-4.

\section{Contact address:}

doc. Ing. Ivan Janoško, CSc., Ing. Tomáš Polonec, Ing. Jozef Chrastina, Department of Transport and Handling, Faculty of Engineering, Slovak University of Agriculture in Nitra, Tr. Andreja Hlinku 2, 94976 Nitra, Slovakia, e-mail: Ivan. Janosko@uniag.sk 